\title{
Chorobowość oraz finansowanie terapii nowotworów w Polsce w latach 2002-2011 według danych Narodowego Funduszu Zdrowia
}

\author{
Andrzej Śliwczyński ${ }^{1,2}$, Adam Rzeźnicki ${ }^{3}$, Tomasz Czeleko², \\ Przemysław Seroczyński ${ }^{4}$, Adam Kozierkiewicz ${ }^{5}$, Jerzy Gryglewicz ${ }^{6}$, \\ Marta Kabatlik-Pytlik ${ }^{2}$, Marcin Pakulski ${ }^{2}$, Maciej Krzakowski ${ }^{7}$
}

Wstęp. Choroby nowotworowe stanowią poważny problem ze względu na ciągle wzrastającą liczbę zachorowań oraz wysokie koszty rozpoznawania i leczenia. Zwiększenie odsetka osób w starszym wieku w połączeniu z większym narażeniem na działanie szkodliwych czynników środowiskowych, jak również rozwój metod diagnostycznych powodują wzrost liczby wykrywanych nowotworów.

Celem pracy było określenie populacji chorych z rozpoznaniem nowotworów w Polsce, oszacowanie wydatków płatnika publicznego związanych z leczeniem przeciwnowotworowym oraz oszacowanie kosztów wprowadzenia nowoczesnych metod leczenia chorych na nowotwory.

Materiał i metody. W celu wykonywania analiz informacji sprawozdawczych w bazach danych NFZ został wykonany moduł analityczny o nazwie „Rejestr Leczenia Chorób” (RLC), który umożliwia pobieranie informacji z bazy danych oraz prezentację danych w czasie rzeczywistym. W analizie przyjęto metodę oszacowania kosztu wprowadzenia innowacji. Przyjęto założenie, że kosztem innowacji staje się wartość środków wydatkowanych przez płatnika publicznego w danym roku, jakie pozostają po ekstrapolowaniu kosztów terapii z roku poprzedniego na liczbę chorych w danym roku. W analizie nie zostały wzięte pod uwagę wartości wskaźnika inflacji. Niepowtarzalnym identyfikatorem danego chorego został uznany numer PESEL. W analizie danych został wykorzystany arkusz kalkulacyjny Excel. Analizę dokonano z wykorzystaniem wszystkich istniejących w bazie pozycji, nie różnicując stopnia wiarygodności potwierdzenia rozpoznania.

Wyniki. Liczba wszystkich wykazywanych chorych z rozpoznaniami nowotworowymi w latach 2002-2012 rosła corocznie i osiągnęła w roku 2011 ponad 1 milion osób leczonych z powodu nowotworów. Dynamika średnioroczna liczby pacjentów względem roku poprzedniego wyniosła ok. $+11 \%$. Rozpoznania, których koszty na przestrzeni całego badanego okresu przekroczyły 10\% budżetu na rozpoznania onkologiczne, obejmują: nowotwór złośliwy sutka (C50) - 14,41\% budżetu i przekroczenie średniorocznego kosztu dla rozpoznań onkologicznych o blisko $1400 \%$ oraz nowotwór złośliwy oskrzeli i płuca (C34) - 10,5\% budżetu i przekroczenie średniorocznego kosztu dla rozpoznań onkologicznych o 1018\%. Rozpoznaniami o najwyższych kosztach średniorocznych w analizowanym okresie były nowotwór złośliwy sutka (C50) - 566944649 PLN oraz nowotwór złośliwy oskrzeli i płuca (C34) - 412877994 PLN. Wyżej wymienione nowotwory stanowiły również rozpoznania o największej liczbie zrealizowanych świadczeń na przestrzeni lat 2002-2011.

\footnotetext{
${ }^{1}$ Oddział Zdrowia Publicznego

Wydział Nauk o Zdrowiu, Uniwersytet Medyczny w Lodzi

${ }^{2}$ Narodowy Fundusz Zdrowia

${ }^{3}$ Zakład Medycyny Społecznej

Uniwersytet Medyczny w Lodzi

${ }^{4}$ Asseco

${ }^{5}$ Ośrodek Analiz Uniwersyteckich

${ }^{6}$ Uczelnia Lazarskiego w Warszawie

${ }^{7}$ Centrum Onkologii — Instytut im. Marii Skłodowskiej-Curie w Warszawie
} 
Wnioski. Przeprowadzone analizy wykazały, że spośród ponad 100 grup rozpoznań nowotworów istnieje około 35, które są istotne z punktu widzenia epidemiologii społecznej. Świadczy to o tym, że Narodowy Program Zwalczania Nowotworów właśnie te choroby powinien potraktować priorytetowo i dla nich powinna być opracowana szczegółowa strategia postępowania. Istnieje około 20 grup rozpoznań, w których obliczony koszt innowacji przekroczył na przestrzeni trzech lat 50 milionów złotych (nowotwory, w leczeniu których wprowadzono nowe leki). Istnieje duża i utrzymująca się w badanym okresie rozbieżność (około 50\%) między wykazywanymi rozpoznaniami i rozpoznaniami potwierdzonymi lub chorymi leczonymi, co wymaga przeprowadzenia odrębnych i bardziej szczegółowych analiz.

\section{Morbidity and financing cancer therapies in Poland between the years $\mathbf{2 0 0 2}$ and 2011 based on the National Health Fund data}

Introduction. Cancer related illnesses are a serious problem due to the always increasing number of such illnesses and the high cost of diagnosis and treatment. The increase in the ratio of elderly people together with the higher risk of exposure to harmful environmental factors and the development of diagnostic methods result in an increased number of diagnosed cancers. The aim of the work was to determine the population of the persons diagnosed with cancer in Poland, evaluate the tax payers' expenses connected with anti-cancer treatment and evaluate costs related to the introduction of the state-of-the-art treatment methods of the ill diagnosed with cancers.

Material and methods. In order to carry out analyses of report information in the NHF data bases, an analytical module was created called the Illness Treatment Register (ITL). This enables downloading of information from the database and presenting it in real time. In the analysis, a method of evaluating the cost of introducing the innovation was assumed. Namely it was assumed that the cost of innovation is the value of funds expended by the public tax payers in a given year that remain, after extrapolation of therapy costs from the previous year per number of ill persons in a given year. The analysis did not consider the value of the inflation index. The PESEL number was considered to be the unique identity number of the ill person. An excel calculation sheet was used in the data analysis which was carried out with the use of all items existing in the database, not differentiating the degree of credibility of diagnosis confirmation.

Results. The number of all the established persons diagnosed with cancer between the years 2002 and 2011 increased annually and reached over 1 million people in 2011 who were treated because of cancers. The average yearly dynamics of the patient numbers compare to the previous year, oscillated around $+11 \%$. Diagnosis that throughout the whole tested period exceeded $10 \%$ of the budget allocated for the oncological diagnoses, included breast cancer (C50) $-14.41 \%$ of the budget and exceeded the average annual cost for oncological diagnoses by nearly $1400 \%$, and bronchi and lungs cancer (C34) - 10.5\% of the budget and exceeded the average annual cost for oncological diagnoses by $1018 \%$. Diagnosis with the highest annual average in the anaysed period were breast cancer (C50) - 566944649 PLN and bronchi and lungs cancer (C34) - 412877994 PLN. The above mentioned cancers were also the diagnoses of the highest number of health services between the years 2002 and 2011.

Conclusions. The analyses showed that from over 100 groups of diagnosed cancers, there are around 35 that are relevant from the point of view of social epidemiology. This indicates that the National Cancer Prevention Programme should treat these illnesses with a high priority and it is for them that a detailed strategy of action ought to be worked out. There are about 20 groups of diagnoses where the calculated cost of innovation exceed 50 million PLN throughout the last three years: for cancers where new medicines were introduced. There is a great and sustaining hiatus in the analysed period (around 50\%) between the reported diagnoses and the confirmed diagnoses for the ill persons that are treated. This requires more detailed analyses.

NOWOTWORY Journal of Oncology 2014; 64, 2: 109-118

Słowa kluczowe: nowotwory, koszty leczenia nowotworów, Polska

Key words: cancers, cancer treatment costs, Poland

\section{Wstęp}

Choroby nowotworowe stanowią poważny problem ze względu na ciągle wzrastającą liczbę zachorowań oraz wysokie koszty rozpoznawania i leczenia. Zwiększenie odsetka osób w starszym wieku w połączeniu z większym narażeniem na działanie szkodliwych czynników środowi- skowych, jak również rozwój metod diagnostycznych powodują, że liczba wykrywanych nowotworów rośnie. Narodowy Program Zwalczania Chorób Nowotworowych — przyjęty w 2005 roku Ustawą [1] — w wersji obowiązującej na lata 2006-2015 zakłada osiągnięcie celów, które obejmują [2]: - zahamowanie wzrostu zachorowań na nowotwory, 
- osiągnięcie wskaźników w zakresie wczesnego wykrywania nowotworów, odpowiadających średnim wartościom w Europie,

- osiągnięcie wskaźników skuteczności leczenia odpowiadających średnim wartościom w Europie,

- stworzenie warunków do wykorzystania w praktyce onkologicznej postępu wiedzy o przyczynach i mechanizmach rozwoju chorób nowotworowych,

- utworzenie systemu ciągłego monitorowania skuteczności zwalczania nowotworów w skali kraju i w poszczególnych regionach kraju.

Realizacja celów w obszernej i zróżnicowanej dziedzinie, jaką jest leczenie chorych na nowotwory, wymaga podsumowania oraz określenia punktu wyjściowego, który stanowić może odniesienie dla oceny realizacji zadań.

Celem obecnego opracowania jest:

a) określenie populacji chorych z rozpoznaniem nowotworów w Polsce,

b) oszacowanie wydatków płatnika publicznego związanych z leczeniem przeciwnowotworowym,

c) oszacowanie kosztów wprowadzenia nowoczesnych metod leczenia chorych na nowotwory.

\section{Materiał i metody}

Świadczenia zdrowotne są w Polsce finansowane przez Narodowy Fundusz Zdrowia (NFZ) na podstawie Ustawy [3] oraz Rozporządzeń Ministra Zdrowia z niej wynikających $[4,5]$. Leczenie chorych na nowotwory odbywa się w ramach umowy o wykonywanie świadczeń w warunkach lecznictwa zamkniętego („umowa szpitalna”). Organizacja, finansowanie i rozliczanie świadczeń są określone dla świadczeniodawców w Zarządzeniach Prezesa NFZ [6, 7]. W latach 2004-2008 — do I połowy 2008 roku — w sposób odrębny były finansowane cytostatyki oraz leki wspomagające, natomiast rozliczanie hospitalizacji było finansowane w ramach umowy szpitalnej. Wraz z wprowadzeniem systemu rozliczeń „Jednorodnych Grup Pacjentów” (JGP) w roku 2008 finansowanie chemioterapii w całości zostało włączone $w$ jedną umowę. Umowa na chemioterapię finansuje obecnie świadczenia rzeczowe (leki) i świadczenia medyczne (pobyt chorego w szpitalu, procedury podania leku i inne).

W celu przeprowadzenia analiz informacji sprawozdawczych w bazach danych NFZ został wykonany moduł analityczny o nazwie „Rejestr Leczenia Chorób” (RLC), który umożliwia pobieranie informacji z bazy danych oraz prezentację danych w czasie rzeczywistym. W zakresie badanego obszaru rozpoznań moduł został zasilony danymi od 1999 roku (w tym - również archiwalnych danych Kas Chorych dotyczących leczenia chorych na nowotwory) z systemów informatycznych oddziałów wojewódzkich NFZ.

Podczas tworzenia bazy danych z systemów informatycznych pobrano informację o leczeniu chorych, u których ustalono rozpoznanie główne - wykazane w sprawoz- daniu rozliczeniowym szpitala - z wykorzystaniem kodu choroby nowotworowej wg ICD-10 od C00 do D09, przypisując niepowtarzalny identyfikator pacjenta (PESEL) oraz wartości kosztowe wypłacone przez płatnika publicznego. Dane obejmowały w szczególności informacje dotyczące chorego i świadczeniodawcy oraz wykonanych procedur medycznych. Rozpoznania zostały podzielone według grup głównych. Bazy danych Kas Chorych oraz — obecnie - NFZ — ze względu na istniejące przepisy - nie zawierają informacji w systemie sprawozdawczym dotyczącej stopnia zaawansowania nowotworu. Jednocześnie w sprawozdaniach rozliczeniowych występuje każdy przypadek chorego (w tym również przypadki, gdy terapia pacjenta kończy się wyłącznie na podejrzeniu choroby nowotworowej). Analiza obejmuje chorobowość (wszystkich wykazanych pacjentów) wraz z wszystkimi przypisanymi do pary „PESEL-ROZPOZNANIE" danymi populacyjnymi i kosztowymi. Zgodnie z definicją "chorobowość" to wskaźnik informujący o tym, ile osób choruje na daną chorobę w danym momencie [8]. Biorąc pod uwagę ww. definicję, analiza jest jak najbardziej uprawniona. Dopiero algorytmy weryfikujące, co z pacjentem dzieje się w dłuższym okresie czasu, pozwalają różnicować tę grupę, ale wymaga to odrębnej analizy, która zostanie przeprowadzona w późniejszym czasie. Dodatkowa przedstawiona praca ma umożliwić dyskusję na temat wyników analizy, co pozwoli lepiej poznać stan polskiej onkologii.

W analizie przyjęto metodę oszacowania kosztu wprowadzenia innowacji według wzoru:

$$
K_{I N N}=K_{t 1}-S K_{t p 1} \times L_{p 1}
$$

gdzie:

$K_{\text {INN }}$ - koszt innowacji

$K_{t 1}$ - suma wydatków na terapię w danym roku

$S K_{t p}$ — średni koszt terapii pacjenta w roku poprzednim

(suma kosztów terapii podzielona przez liczbę pacjentów)

$L_{p 1}$ - liczba pacjentów w danym roku

Przykład dla roku 2008:

$$
K_{\text {INN2008 }}=K_{t 200 a}-S K_{t p 2007} \times L_{p 2008}
$$

W analizie przyjęto założenie, że kosztem innowacji staje się wartość środków wydatkowanych przez płatnika publicznego w danym roku, pozostających po ekstrapolowaniu kosztów terapii z roku poprzedniego na liczbę chorych w danym roku. W analizie, dla obliczenia kosztów innowacji, nie zostały wzięte pod uwagę wartości wskaźnika inflacji. Niepowtarzalnym identyfikatorem danego chorego został uznany numer PESEL.W analizie danych został wykorzystany arkusz kalkulacyjny Excel.

Analizę dokonano z wykorzystaniem wszystkich istniejących w bazie pozycji, nie różnicując stopnia wiarygodności 


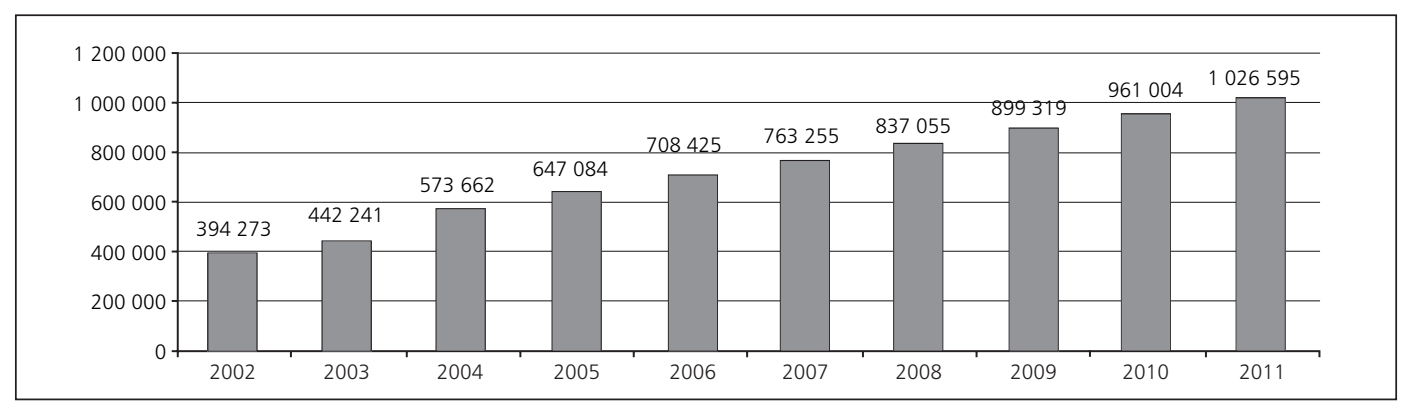

Rycina 1. Liczba chorych w danym roku kalendarzowym w latach 2002-2011

Tabela II. Rozpoznania charakteryzujące się dużą dynamiką wzrostu w roku 2008

\begin{tabular}{lll}
\hline ICD-10 & Nazwa kodu & 2008 (\%) \\
\hline C76 & Nowotwór złośliwy umiejscowień innych i niedokładnie określonych & 44 \\
D02 & Rak in situ ucha środkowego i układu oddechowego & 35 \\
C65 & Nowotwór złośliwy miedniczki nerkowej & 29 \\
C93 & Białaczka monocytowa & 28 \\
D09 & Rak in situ innych i nieokreślonych umiejscowień \\
C39 & Nowotwór złośliwy innych i niedokładnie określonych układu oddechowego i narządów klatki piersiowej \\
C78 & Wtórne nowotwory złośliwe układu oddechowego i trawiennego \\
D04 & Rak in situ skóry & 27 \\
D01 & Rak in situ innych i nieokreślonych części narządów trawiennych & 26 \\
\hline
\end{tabular}

potwierdzenia rozpoznania. Ze względu na brak w systemach informatycznych NFZ pewnej części danych (np. informacje na temat stopnia zaawansowania oraz rozpoznania patomorfologicznego nowotworu) nie ma możliwości precyzyjnego określenia docelowej populacji chorych. Na potrzeby obecnej analizy pod uwagę zostały wzięte wszystkie doniesienia o rozpoznaniu nowotworowym, a w kolejnej analizie zostało zaplanowane ograniczenie danych wyłącznie do populacji o potwierdzonym rozpoznaniu. Niemniej jednak ze względu na dużą liczebność dane terytorialne i demograficzne oraz finansowe zachowują swoją integralność.

\section{Wyniki}

Na podstawie przekazywanego w raportach statystycznych numeru PESEL chorego oraz wykazywanego rozpoznania ICD-10, w oparciu o parametryzację określoną w metodologii badań system informatyczny przyporządkował chorych do dominującego rozpoznania nowotworu. Na tej podstawie określono liczebność populacji w poszczególnych latach odnoszącą się do grup rozpoznań (tab. I — tylko w wersji elektronicznej artykułu).

Sposób pobierania danych z systemów informatycznych w zakresie wskazanej w tabeli I (tabela tylko w wersji elektronicznej artykułu) „populacji pacjentów wraz z przyporządkowanymi im rozpoznaniami" nie pozwala na sumowanie w obrębie roku. Prawdopodobna jest sytuacja wskazania dwóch lub więcej rozpoznań dotyczących jednego pacjenta.
Poprawność danych w tabeli I (tabela tylko w wersji elektronicznej artykułu) jest zachowana w obrębie wiersza, czyli grupy rozpoznań wskazanych danym kodem ICD-10.

Sumaryczna liczba niepowtarzalnych numerów PESEL w obrębie jednego roku została przedstawiona na rycinie 1; pobieranie danych w tym przypadku sumowało dany numer PESEL wyłącznie raz w obrębie danego roku.

Liczba wszystkich wykazywanych chorych z rozpoznaniami nowotworowymi w latach 2002-2011 rosła corocznie i osiągnęła w roku 2011 ponad 1 milion osób leczonych z powodu nowotworów. Dynamika liczby pacjentów średnioroczna względem roku poprzedniego wyniosła ok. $+11 \%$ (ryc. 1, tab. II). Należy przypuszczać, że świadomość lekarzy oraz pacjentów w zakresie rozpoznawania chorób nowotworowych w badanym okresie bardzo wzrosła, a kierowanie na bardziej szczegółową diagnostykę pacjentów w przypadku podejrzenia choroby przynosi oszczędności społeczne związane z wcześniejszym wykryciem i skuteczniejszą terapią. Przełomowym rokiem jest rok 2004, w którym liczba sprawozdanych chorych na nowotwory zwiększyła się o 30\%. Wydaje się, że jest to związane między innymi ze zmianą organizacji świadczeń opieki zdrowotnej i powołaniem NFZ, co przyczyniło się do wyraźnej poprawy sprawozdawanych danych. Przyczyny tej zmiany muszą być poddane osobnej analizie. Najwyższy, ponad 100-procentowy przyrost populacji zanotowano w przypadku rozpoznań wymienionych w tabeli III. 
Tabela III. Lista rozpoznań charakteryzujących się dużą dynamiką w roku 2004

\begin{tabular}{llc}
\hline ICD-10 & Nazwa kodu & 2004 (\%) \\
\hline D00 & Rak in situ jamy ustnej, przełyku i żołądka & 2430 \\
D01 & Rak in situ innych i nieokreślonych części narządów trawiennych & 2160 \\
D04 & Rak in situ skóry & 1330 \\
D06 & Rak in situ szyjki macicy & 865 \\
D02 & Rak in situ ucha środkowego i układu oddechowego & 800 \\
D07 & Rak in situ innych i nieokreślonych narządów płciowych & 763 \\
D03 & Czerniak in situ & 517 \\
D09 & Rak in situ innych i nieokreślonych umiejscowień & 400 \\
D05 & Rak in situ sutka & 362 \\
C14 & Nowotwór złośliwy o innym i o bliżej nieokreślonym umiejscowieniu w obrębie wargi, jamy ustnej i gardła & 213 \\
C68 & Nowotwór złośliwy innych i nieokreślonych lokalizacji narządów moczowych & 181 \\
\hline
\end{tabular}

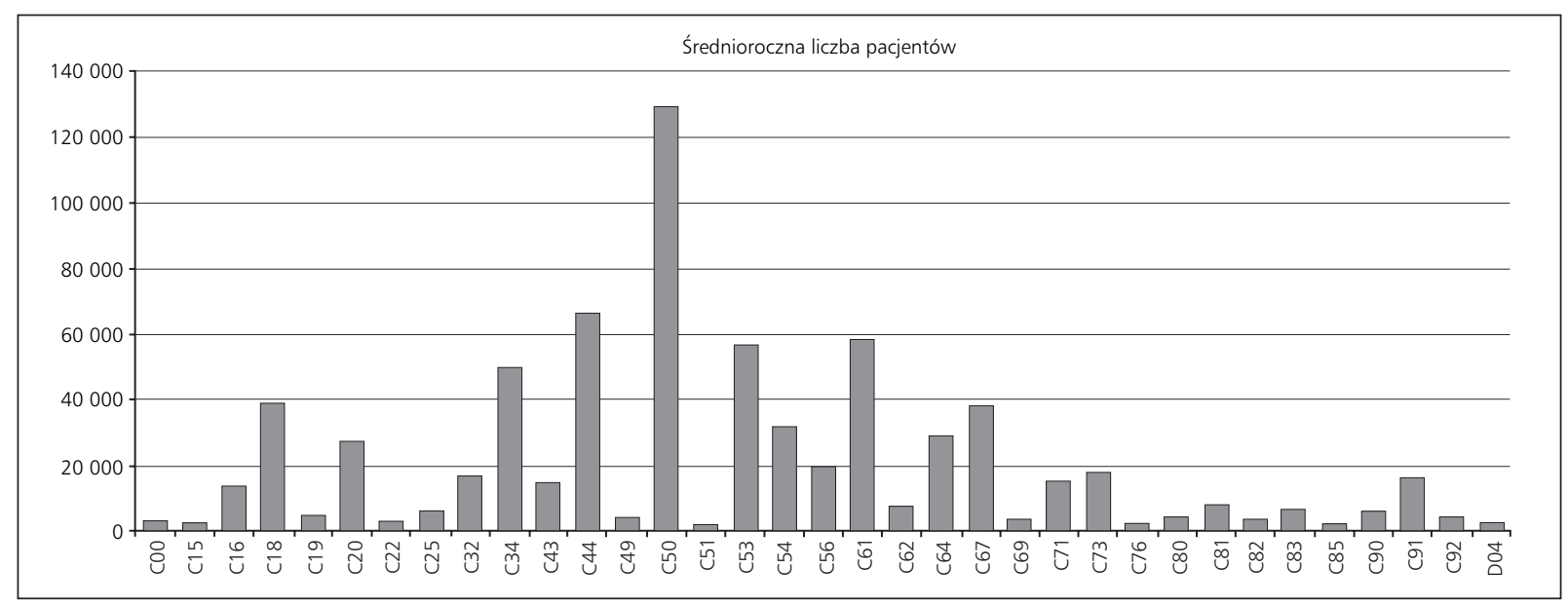

Rycina 2. Rozpoznania nowotworów, dla których średnia wartość rocznej liczby chorych przekracza 2000 osób

Podobnie wyższy niż przeciętny przyrost liczby chorych zanotowano również w roku 2008 (ryc. 1). Przyczyną było wprowadzenie systemu rozliczeń JGP, co spowodowało kolejną poprawę jakości sprawozdawanych danych (w tym umożliwienie sprawozdawania rozpoznań współistniejących).

W związku z dużym zróżnicowaniem średniej liczby chorych w poszczególnych rozpoznaniach dalsze analizy zostały wykonane dla rozpoznań ze średnią liczbą chorych rocznie powyżej 2000 (ryc. 2).

Liczebność populacji z rozpoznaniami, w których średnioroczna liczba chorych przekracza 2000 osób, stanowi 94\% ogólnej populacji z rozpoznaniami nowotworów. Na pierwszym miejscu występują następujące rozpoznania: „nowotwór złośliwy sutka” (C50) o średniorocznej populacji wynoszącej 129513 osób, ,inne nowotwory złośliwe skóry" (C44), o średniorocznej populacji wynoszącej 66649 osób, „nowotwór złośliwy gruczołu krokowego" (C61), o populacji 58782 osób oraz „nowotwór złośliwy oskrzeli i płuca” (C34), o populacji wynoszącej 50340 osób (ryc. 2).

\section{Wydatki ze środków publicznych (koszty)}

Finansując świadczenia opieki zdrowotnej zgodnie z Ustawą [3], NFZ wymaga sprawozdawania świadczeń, które są wykonywane dla każdego chorego. Do roku 2008 w sprawozdawczości występowało wyłącznie jedno rozpoznanie, systemy informatyczne oraz przepisy nie przewidywały wykazywania innych rozpoznań niż stanowiące podstawę rozpoczęcia leczenia. Wspomniane rozwiązanie skutkowało zbyt dużą liczbą sprawozdanych chorych z rozpoznaniami będącymi wyłącznie „markerami” wykonywanych zabiegów (np. Z51.1 - cykle chemioterapii) i powodowało problemy z obliczeniem kosztów. Dopiero ustalenie rozpoznania dominującego dla każdego chorego i zsumowanie kosztów wszystkich wykonanych procedur pozwoliło zobrazować wydatki (tab. IV — tylko w wersji elektronicznej artykułu).

Podobnie do przypadku populacji chorych można wyodrębnić rozpoznania o dużej kosztochłonności (tab. IV - tylko w wersji elektronicznej artykułu, ryc. 3. Rozpoznania, których koszty na przestrzeni całego bada- 


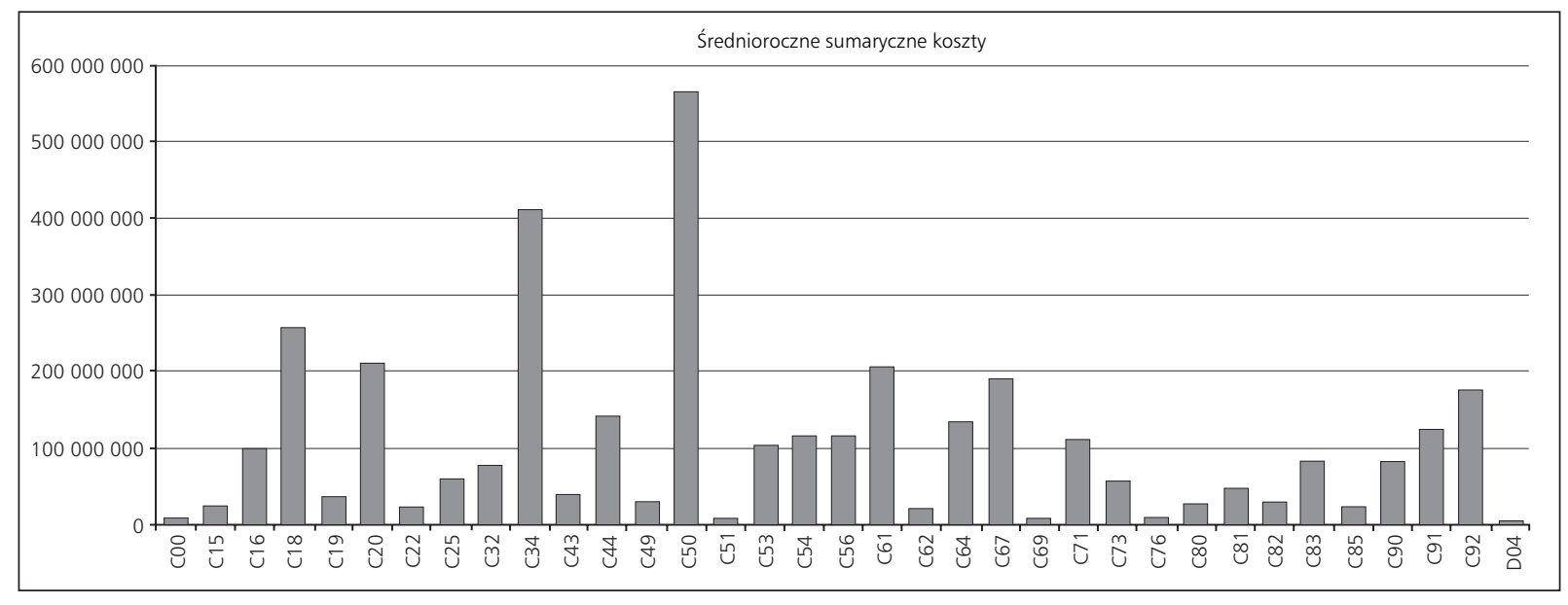

Rycina 3. Sumaryczna wartość finansowania dla rozpoznań, w których średnia liczba chorych rocznie przekraczała 2000 osób

nego okresu przekroczyły $5 \%$ budżetu na rozpoznania onkologiczne, obejmują:

- nowotwór złośliwy sutka (C50) - 14,41\% budżetu - 566944649 zł (przekroczenie średniego rocznego kosztu dla rozpoznań onkologicznych o blisko 1400\%),

- nowotwór złośliwy oskrzeli i płuca (C34) - 10,5\% budżetu - 412877994 zł (przekroczenie średniego rocznego kosztu dla rozpoznań onkologicznych o 1018\%),

- nowotwór złośliwy okrężnicy (C18) - 6,55\% budżetu - 257782678 (przekroczenie średniego rocznego kosztu dla rozpoznań onkologicznych o 635\%),

- nowotwór złośliwy odbytnicy (C20) - 5,38\% budżetu - 211745907 (przekroczenie średniego rocznego kosztu dla rozpoznań onkologicznych o 522\%),

- nowotwór złośliwy gruczołu krokowego (C61) - 5,27\% budżetu - 176304997 (przekroczenie średniego rocznego kosztu dla rozpoznań onkologicznych o 511\%). Najniższy poziom kosztów $(0,01 \%$ budżetu na rozpoznania onkologiczne), zaobserwowano:

- nowotwór złośliwy łożyska (C58),

- nowotwór złośliwy innych i nieokreślonych męskich narządów płciowych (C63),

— rak in situ jamy ustnej, przełyku i żołądka (D00),

- rak in situ innych i nieokreślonych części narządów trawiennych (D01),

- rak in situ ucha środkowego i układu oddechowego (D02),

- czerniak in situ (D03), rak in situ innych i nieokreślonych lokalizacji narządów płciowych (D07),

- rak in situ innych i nieokreślonych umiejscowień (D09).

Rozpoznania o średniorocznych kosztach (suma kosztów dzielona przez liczbę lat dla danego rozpoznania) w badanym okresie poniżej 1 miliona złotych obejmują (tab. IV — tylko w wersji elektronicznej artykułu):
- rak in situ ucha środkowego i układu oddechowego (D02) - 139425 ,

- czerniak in situ (D03) - 207 071,

- rak in situ innych i nieokreślonych lokalizacji umiejscowień (D09) - 303 212,

- rak in situ innych i nieokreślonych lokalizacji narządów płciowych (D07) - 324 771,

- nowotwór złośliwy łożyska (C58) - 497 872,

- rak in situ jamy ustnej, przełyku i żołądka (D00) $-508022$

- rak in situ innych i nieokreślonych części narządów trawiennych (D01) - 533008 ,

- nowotwór złośliwy innych i nieokreślonych lokalizacji męskich narządów płciowych (C63) - 551 443,

- nowotwór złośliwy tchawicy (C33) - 793056 ,

- mięsak Kaposiego (C46) - 807 396,

- nowotwór złośliwy innych i niedokładnie określonych części układu oddechowego i narządów klatki piersiowej (C39) - 950 803,

- białaczka z komórek nieokreślonego rodzaju (C95) - 991124.

Najwyższy przyrost kosztów miał miejsce w 2004 roku i wyniósł 76\% względem roku poprzedniego, po czym dynamika sukcesywnie spadała do 9\% w 2007 roku. W latach 2008 i 2009 miał miejsce kolejny znaczący wzrost kosztów, odpowiednio 37\% i 38\% względem poprzednich lat. W kolejnych latach przyrost kosztów ustabilizował się na poziomie do $10 \%$ (ryc. 5).

Wzrost kosztów z lat 2004, 2008 i 2009 nie wykazywał bezpośredniej zależności ze wzrostem liczby leczonych pacjentów, lecz z wprowadzeniem innowacyjnych i bardziej kosztownych metod leczenia.

Ekstrapolacja kosztów innowacji była możliwa przy przyjęciu założenia, że średni koszt pojedynczego świadczenia udzielonego chorym w leczeniu chorób nowotworowych jest 


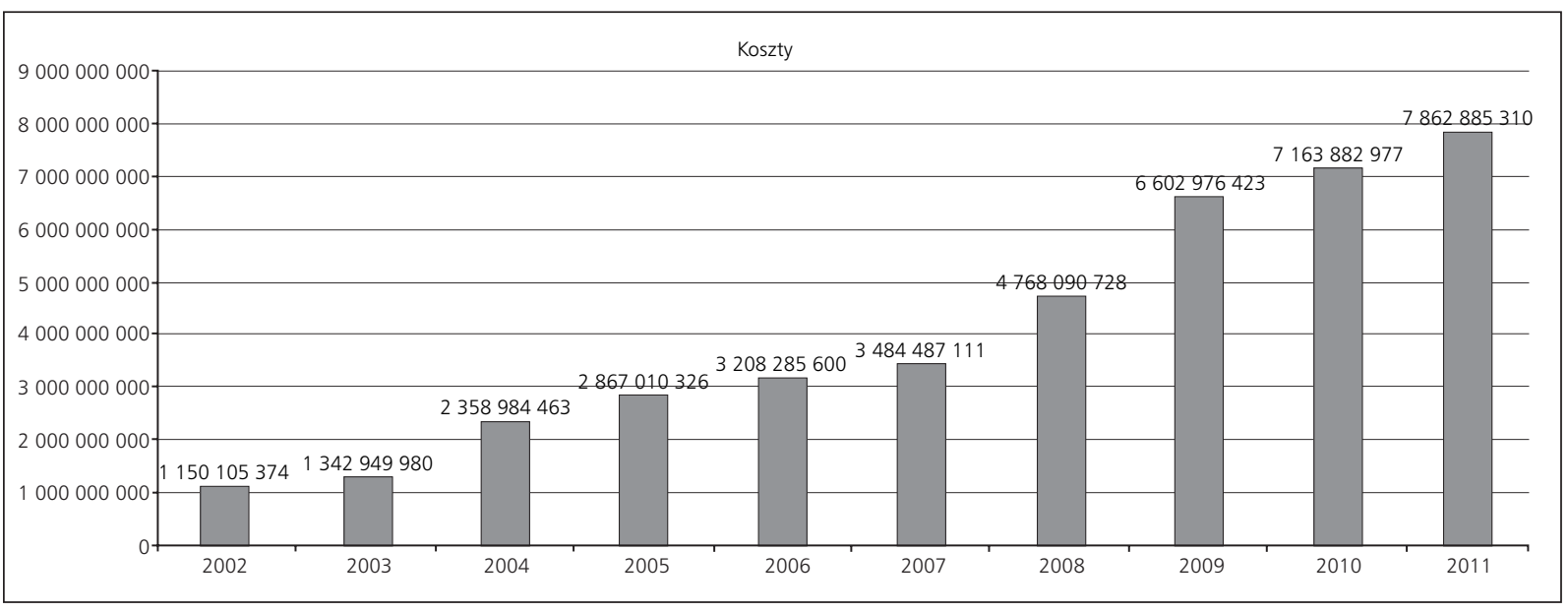

Rycina 4. Sumaryczna wartość wydatków płatnika publicznego w zł w latach 2002-2012

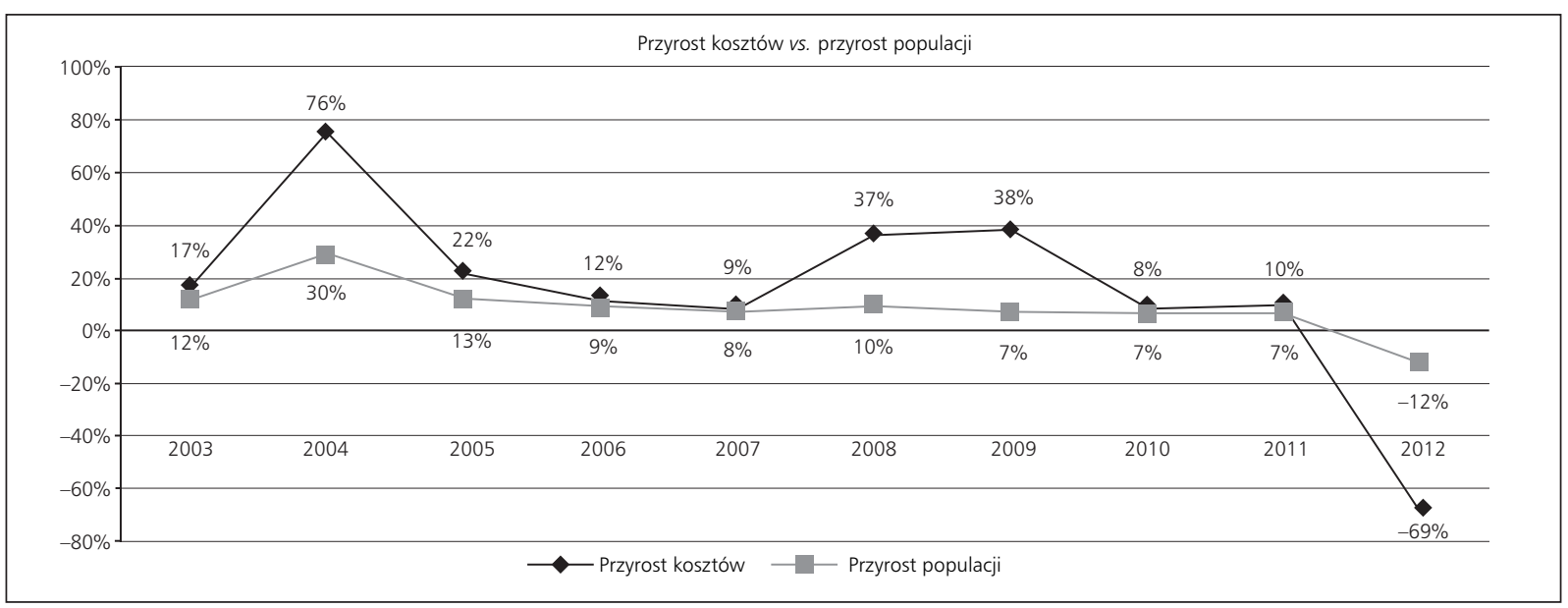

Rycina 5. Porównanie dynamiki zmian kosztów w odniesieniu do dynamiki zmian populacji

Tabela V. Przewidywanie kosztów wprowadzenia nowych technologii medycznych wartości w tysiącach złotych

\begin{tabular}{|c|c|c|c|c|c|c|c|c|c|c|}
\hline & 2002 & 2003 & 2004 & 2005 & 2006 & 2007 & 2008 & 2009 & 2010 & 2011 \\
\hline Koszt & 1150105 & 1342950 & 2358984 & 2867010 & 3208285 & 3484487 & 4768090 & 6602976 & 7163882 & 7862885 \\
\hline Przyrost populacji & & $12 \%$ & $30 \%$ & $13 \%$ & $9 \%$ & $8 \%$ & $10 \%$ & $7 \%$ & $7 \%$ & $7 \%$ \\
\hline $\begin{array}{l}\text { Koszt powiększony } \\
\text { o wzrost populacji }\end{array}$ & & 1290029 & 1742035 & 2660906 & 3138791 & 3456597 & 3821406 & 5122763 & 7055879 & 7652836 \\
\hline Koszt innowacji & & 52920 & 616949 & 206103 & 69494 & 27889 & 946684 & 1480213 & 108003 & 210048 \\
\hline $\begin{array}{l}\text { Koszt innowacji jako } \\
\text { procent kosztów } \\
\text { z poprzedniego roku }\end{array}$ & & $5 \%$ & $46 \%$ & $9 \%$ & $2 \%$ & $1 \%$ & $27 \%$ & $31 \%$ & $2 \%$ & $3 \%$ \\
\hline
\end{tabular}

zbliżony do średniego kosztu tego świadczenia w poprzednim okresie (wiersz w tabeli V odnoszący się do „Kosztu powiększonego o wzrost populacji" ukazuje przewidywane koszty w kolejnych latach zuwzględnieniem przyrostu populacji chorych). Koszty rzeczywiste jednak bardzo odbiegają od oczekiwanego poziomu. Różnica miedzy kosztami rzeczywistymi w poszczególnych latach i oczekiwanym poziomem kosztów z wiersza „Koszt powiększony o wzrost populacji"została ujęta w wierszu „Koszt innowacji” (koszt, który nie wynika z przyrostu populacji), tabela V, tabela VIII — wersja elektroniczna.

W tabeli $V$ przedstawiono koszt innowacyjnego leczenia skorygowany o przyrost populacji ${ }^{1}$. Najwyższe

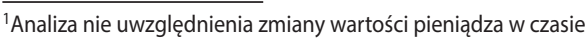


Tabela VI. Rozpoznania, dla których koszty innowacji na przestrzeni 3 lat przekroczyły 50 milionów złotych

\begin{tabular}{|c|c|c|c|c|c|}
\hline \multicolumn{2}{|r|}{ Rozpoznanie } & 2004 & \multicolumn{2}{|c|}{\begin{tabular}{|r|}
2008 \\
\end{tabular}} & RAZEM \\
\hline ICD-10 & Nazwa kodu & \begin{tabular}{|l|} 
Kos zt innowacji \\
(skorygowany o \\
wzrost kos ztów \\
wynikający ze wzros tu \\
populacji)
\end{tabular} & \begin{tabular}{|l|} 
Kos zt innowacji \\
(s korygowany o \\
wzrost kos ztów \\
wynikający ze wzrostu \\
populacji)
\end{tabular} & \begin{tabular}{|l|} 
Koszt innowacji \\
(skorygowany o \\
wzrost kos ztów \\
wynikający ze wzros tu \\
populacji)
\end{tabular} & $\begin{array}{c}\text { Suma kos ztów } \\
\text { innowacji na } \\
\text { przestrzeni } \\
2004 / 2008 / 2009\end{array}$ \\
\hline C16 & NOWOTWÓR ZૈOŚLIWY ŻOŁĄDKA & $\square 14010575,55 \mathrm{zt}$ & $\square 26620826,42 \mathrm{zt}$ & $39958928,23 \mathrm{zt}$ & $80590330,20 \mathrm{zf}$ \\
\hline C18 & NOWOTWÓR ZZOŚLIWY JELITA GRUBEGO & $18348118,50 \mathrm{zt}$ & $70768504,40 \mathrm{zt}$ & $106078423,17 \mathrm{zf}$ & $195195046,07 \mathrm{zł}$ \\
\hline $\mathrm{C} 20$ & NOWOTWÓR ZૈOŚLIWY ODBYTNICY & $31007095,76 z$ & $44715206,30 \mathrm{zt}$ & $77599106,11 \mathrm{z} \nmid$ & $153321408,17 \mathrm{zt}$ \\
\hline $\mathrm{C} 25$ & NOWOTWÓR ZLOŚLIWY TRZUSTKI & $8649084,90 \mathrm{zt}$ & $16573446,40 \mathrm{zt}$ & 26018523,32 z & $51241054,62 \mathrm{zf}$ \\
\hline C32 & NOWOTWÓR ZłOŚLIWY KRTANI & $19265276,72 \mathrm{zt}$ & $16022347,67 \mathrm{zt}$ & 39347605,74 z't & $74635230,12 \mathrm{zt}$ \\
\hline $\mathrm{C} 34$ & NOWOTWÓR ZłOŚLIWY OSKRZELA I PŁUCA & $63615353,05 \mathrm{zt}$ & $104189206,87 \mathrm{zh}$ & 169981378,58 z zł & $337785938,51 \mathrm{zt}$ \\
\hline $\mathrm{C} 44$ & INNE NOWOTWORY ZtOŚLIWE SKÓRY & $18659783,26 \mathrm{zt}$ & $35675829,44 \mathrm{zt}$ & $45141464,84 \mathrm{zt}$ & $99477077,54 \mathrm{zt}$ \\
\hline $\mathrm{C} 50$ & NOWOTWÓR ZłOŚLIWY SUTKA & $84467553,45 \mathrm{zt}$ & $184338552,71 \mathrm{zt}$ & $212953807,00 \mathrm{zt}$ & $481759913,15 \mathrm{z}$ \\
\hline $\mathrm{C} 53$ & NOWOTWÓR ZLOŚLIWY SZYJKI MACICY & $23851291,40 \mathrm{zt}$ & $18506701,26 \mathrm{zt}$ & 38908377,74 zł & $81266370,41 \mathrm{zf}$ \\
\hline C54 & NOWOTWÓR ZłOŚLIWY TRZONU MACICY & 23782806,44 zł & $25402602,68 \mathrm{zt}$ & 41075525,12 zł & $90260934,25 \mathrm{zł}$ \\
\hline C56 & NOWOTWÓR ZłOŚLIWY JAJNIKA & $15938367,07 \mathrm{zt}$ & $31030025,38 \mathrm{zt}$ & $28641794,85 \mathrm{zt}$ & $75610187,30 \mathrm{zf}$ \\
\hline C61 & NOWOTWÓR ZŁOŚLIWY GRUCZOŁU KROKOWEGO & $50141713,52 \mathrm{zt}$ & $48558353,77 \mathrm{zt}$ & $102598675,35 \mathrm{z}$ - & $201298742,65 \mathrm{zt}$ \\
\hline $\mathrm{C} 64$ & NOWOTWÓR ZłOŚLIWY NERKI, Z WYJĄTKIEM MIEDNICZKI NERKOWEJ & $11722307,73 \mathrm{zt}$ & $36096070,18 \mathrm{zł}$ & $62628949,80 \mathrm{zt}$ & $110447327,70 \mathrm{zf}$ \\
\hline C67 & NOWOTWÓR ZłOŚLIWY PĘCHERZA MOCZOWEGO & $33008189,12 \mathrm{zh}$ & $43890659,02 \mathrm{zt}$ & $64002196,58 \mathrm{zt}$ & 140901044,72 zł \\
\hline C71 & NOWOTWÓR ZłOŚLIWY MÓZGU & $20840260,10 \mathrm{z}\}$ & $13988312,68 \mathrm{zt}$ & $43446210,07 \mathrm{zt}$ & $78274782,85 \mathrm{zf}$ \\
\hline C73 & NOWOTWÓR ZłOŚLIWY TARCZYCY & $11870914,74 \mathrm{zt}$ & $14761416,86 \mathrm{zt}$ & $28063846,77 \mathrm{zf}$ & $54696178,37 \mathrm{zł}$ \\
\hline $\mathrm{C} 83$ & CHŁONIAKI NIEZARNICZE ROZLANE & $17517886,15 \mathrm{z}$ & $23163296,92 \mathrm{z}$ & 23529194,27 zł & $64210377,33 \mathrm{zf}$ \\
\hline $\mathrm{C} 90$ & SZPICZAK MNOGI I NOWOTWORY ZłOŚLIWE Z KOMÓREK PLAZMATYCZNYCH & 9845130,62 가 & $33297439,68 \mathrm{zt}$ & $21728383,20 \mathrm{zh}$ & $64870953,50 \mathrm{zł}$ \\
\hline C91 & BIALACZKA UMFATYCZNA & $24436505,98 \mathrm{z}\}$ & $24551028,56 \mathrm{zt}$ & $54318714,51 \mathrm{z}\}$ & $103306249,05 \mathrm{zt}$ \\
\hline C92 & BIALACZKA SZPIKOWA & $46332395,38 \mathrm{zt}$ & $44699701,71 \mathrm{zt}$ & $66690161,57 \mathrm{z}+$ & $157722258,66 \mathrm{zt}$ \\
\hline
\end{tabular}

Tabela VII. Rozpoznania, dla których koszty innowacji na przestrzeni 3 lat przekroczyły 200 milionów złotych

\begin{tabular}{|c|c|c|c|c|c|}
\hline & & 2004 & 2008 & 2009 & Razem \\
\hline ICD-10 & Nazwa kodu & $\begin{array}{l}\text { Koszt innowacji } \\
\text { (skorygowany o wzrost } \\
\text { kosztów wynikający ze } \\
\text { wzrostu populacji) }\end{array}$ & \begin{tabular}{|l|} 
Koszt innowacji \\
(skorygowany o wzrost \\
kosztów wynikający ze \\
wzrostu populacji) \\
\end{tabular} & \begin{tabular}{|l|} 
Koszt innowacji \\
(skorygowany o wzrost \\
kosztów wyni kający ze \\
wzrostu populacji) \\
\end{tabular} & $\begin{array}{l}\text { Suma kosztów } \\
\text { innowacji na } \\
\text { prze strzeni } \\
2004 / 2008 / 2009\end{array}$ \\
\hline $\mathrm{C} 34$ & NOWOTWÓR ZŁOŚLIWY OSKRZELAIPŁUCA & $63615353,05 \mathrm{zh}$ & $104189206,87 \mathrm{zf}$ & $169981378,58 \mathrm{z}+$ & $337785938,51 \mathrm{zł}$ \\
\hline $\mathrm{C} 50$ & NOWOTWÓR ZŁOŚLIWY SUTKA & $84467553,45 \mathrm{zH}$ & $184338552,71 \mathrm{zt}$ & $212953807,00 \mathrm{z} t$ & $481759913,15 \mathrm{z}$ \\
\hline C61 & NOWOTWÓR ZŁOŚLIWY GRUCZOŁU KROKOWEGO & $50141713,52 \mathrm{zh}$ & $48558353,77 \mathrm{zf}$ & $102598675,35 \mathrm{zf}$ & $201298742,65 \mathrm{zh}$ \\
\hline
\end{tabular}

koszty innowacji zostały poniesione w latach 2004, 2008 i 2009.

Tabela VI przedstawia koszty innowacji w latach 2004, 2008 i 2009 dla wszystkich rozpoznań oraz proporcję względem kosztów z roku poprzedzającego. Istnieje grupa rozpoznań, na którą w latach 2004, 2008 i 2009 poniesiono wyjątkowo wysokie koszty innowacji (tabela VI i VII — z podziałem na wysokość inwestycji w innowacyjne rozwiązania powyżej 50 milionów oraz powyżej 200 milionów na przestrzeni 3 lat).

Tabela VII przedstawia rozpoznania, dla których koszty innowacji na przestrzeni trzech rozpatrywanych okresów przekroczyły $200 \mathrm{mln}$ zł. Są to rozpoznania o największej liczbie chorych.

Są również rozpoznania, które w czasie dużych nakładów na innowacje mają przyrost ujemny (tab. VIII — tylko w wersji elektronicznej artykułu). Przykładem może być:

— nowotwór złośliwy o innym i o bliżej nieokreślonym umiejscowieniu w obrębie wargi, jamy ustnej i gardła (C14) — spadek o 97\%,

- nowotwór złośliwy kości i chrząstki stawowej kończyn (C40) - spadek o 19\%,

— rak in situ innych i nieokreślonych umiejscowień (D09) — spadek o 197\% w 2004 roku,

- mięsak Kaposiego (C46) - spadek o 25\%,

— nowotwór złośliwy łożyska (C58) — spadek o 17\%,
- rak in situ ucha środkowego i układu oddechowego (D02) - spadek o 27\% w 2008 roku.

Pozytywną tendencją było zmniejszenie kosztów w rozpoznaniach bliżej nieokreślonych nowotworów, jak C14 i D09. Tabela VI przedstawia rozpoznania, które na przestrzeni lat 2004 i 2008-2009 były szczególnie objęte innowacjami. Warto zwrócić uwagę na fakt, że poziom dofinansowania innowacyjnych rozwiązań w poszczególnych latach jest bardzo podobny. Rozpoznania, dla których koszty innowacji na przestrzeni trzech rozpatrywanych okresów przekroczyły $200 \mathrm{ml}$ zł, są jednocześnie rozpoznaniami o największej liczbie chorych (tab. VI i VII):

- nowotwór złośliwy oskrzeli i płuca (C34) —średnioroczna liczba pacjentów to 50340 osób,

- nowotwór złośliwy sutka - populacja 129513 osób,

- nowotwór złośliwy gruczołu krokowego (C61) - 58782 osób.

\section{Omówienie}

Świadczenia związane z leczeniem chorych na nowotwory są jednymi z ważniejszych działań w zakresie ochrony zdrowia. Ogromną rolę problemów medycznych związanych z nowotworami podkreśla przyjęty i realizowany Narodowy Program Zwalczania Chorób Nowotworowych na lata 2006-2015. Analizując liczbę chorych z rozpoznaniami onkologicznymi (grupy ICD-10 „C" ${ }_{\text {;" }} \mathrm{D}^{\prime \prime}$ ), których uwzględniono 
w sprawozdaniach w poszczególnych latach, obserwujemy wzrost o rocznej dynamice około 8\% (wyjątkiem jest rok 2004, w którym dynamika osiąga +30\% oraz 2008 rok z wartością $+10 \%)$. Wspomniane wartości mogą mieć jednak związek ze zmianą organizacyjną udzielania świadczeń oraz z systemami rozliczeniowymi, jakie funkcjonowały w tych latach (rok 2004 — „wprowadzenie” NFZ, rok 2008 - wprowadzenie systemu JGP). Spośród wszystkich rozpoznań około 35 wydaje się być istotnym problemem społecznym, ponieważ w przypadku wspomnianych rozpoznań średnioroczna liczba chorych przekroczyła 2000 osób. Grupą największą o liczbie chorych powyżej 150000 są nowotwory złośliwe sutka (przy założeniu, że nadrozpoznawalność ma wartość identyczną z ogólną, można oszacować, że populacja chorych faktycznie leczonych wynosi około 80000 osób, co wprost przekłada się na wartość środków finansowych wydatkowanych przez płatnika). Następnymi w kolejności rozpoznaniami są: „C44 - Inne nowotwory złośliwe skóry" oraz „C61 - nowotwory złośliwe gruczołu krokowego”. W przypadku tych rozpoznań populacja potencjalnych pacjentów zbliża się do 100000 osób („C44" - 111 tys. osób w 2011 roku, „,C61" - 82000 osób w 2011 roku). Analiza wykazała ponadto grupę rozpoznań, w których liczba chorych na przestrzeni 11 lat jest niewielka i wynosi średnio w ciągu roku poniżej 2 000. Najniższe wskaźniki średniej wykazują rozpoznania "D02 — rak in situ ucha środkowego i układu oddechowego" oraz "D09 — rak in situ innych i nieokreślonych umiejscowień" (średnia liczba chorych rocznie poniżej 50 osób). W grupie rozpoznań „C" najniższą wartość (około 100 osób średnio w ciągu roku) wykazano dla rozpoznań „C33 - nowotwór złośliwy tchawicy".

Wartość środków, jakie płatnik publiczny przeznacza na leczenie chorych z rozpoznaniami "C" oraz „D" rośnie corocznie od 2002 roku i w 2011 roku osiągnęła około 8 miliardów złotych. Najwyższa dodatnia dynamika wystąpiła w 2004 roku (około $+75 \%$ ) oraz w 2008 roku (około $+37 \%$ ). Średnio w badanym okresie (lata 2002-2011) wzrost nakładów na leczenie chorych na nowotwory wyniósł $+25 \%$ przy porównywaniu kolejnych lat. W porównaniu do stanu wyjściowego (2002 roku) wzrost wyniósł 683\% (wartość 1,15 miliarda w 2002 roku i 7,86 miliarda złotych w 2011 roku). Przyrost nakładów był w badanym okresie większy od przyrostu populacji leczonych chorych, a większe różnice wystąpiły w latach ze zmianami organizacyjnymi (2004 rok oraz lata 2008/2009, gdzie dynamika zwiększania środków finansowych wynosiła DŚF $F_{2004}=+76 \%$; DŚF $_{2008}=+37 \%$; DŚF $F_{2009}=+38 \%$, natomiast dynamika wzrostu liczby leczonych chorych wyniosła $\mathrm{DLP}_{2004}=+30 \%$; $\mathrm{DLP}_{2008}=+10 \% ; \mathrm{DLP}_{2009}=+7 \%$ ). Dynamiczny wzrost nakładów przełożył się na finansowanie nowych leków. Obliczony koszt innowacyjnych leków w badanym okresie wynosił średnio około 14\% i był najwyższy w latach zmian organizacyjnych (2004 rok $=46 \%$; 2008 rok $=27 \%$; 2009 rok $=31 \%)$, przy najwyższym koszcie innowacji dla rozpoznań „C50", "C34" oraz „C18”. W grupie około 20 rozpoznań koszt innowacji w latach 2002-2011 był najwyższy. W obliczonym koszcie innowacji występują również wartości ujemne dla rozpoznań „C58 nowotwór złośliwy łożyska” oraz, C55 nowotwór złośliwy nieokreślonej części macicy”, co było związane z leczeniem mniejszej liczby chorych w kolejnych latach. Pozytywną tendencją jest zmniejszanie kosztów w rozpoznaniach „nieokreślone” (np. „C14" oraz „D09”), co świadczy o coraz dokładniejszej i precyzyjniejszej diagnostyce.

Z informacji zawartych w sprawozdaniach i danych użytych w analizie wynika korelacja między wartościami określonymi dla „liczba populacji”, „wartość nakładów” i„,liczba świadczeń”. Wskaźnik korelacji liniowej r-Pearsona przyjmuje wartość bardzo silną dodatnią i dla poszczególnych grup danych wynosi:

\begin{tabular}{|l|l|l|}
\hline liczba populacji & wartość nakładów & 0,876031 \\
\hline wartość nakładów & liczba świadczeń & 0,883018 \\
\hline liczba świadczeń & liczba populacji & 0,920180 \\
\hline
\end{tabular}

Występuje dodatnia dynamika przyrostu średniego kosztu świadczenia względem przyrostu liczby udzielonych świadczeń (rok/rok). Wyjątkowymi latami (dynamika wzrostu średniego kosztu świadczenia mniejsza od dynamiki wzrostu liczby świadczeń) są lata 2006 oraz 2010 - wartości wynoszą odpowiednio $D_{\mathrm{L} 2006}={ }_{"}-9^{\prime \prime} ; D_{\mathrm{K} 2006}={ }_{"}+37$ " oraz $\mathrm{D}_{\mathrm{L} 2010}={ }_{\text {" }}+5^{\prime \prime} ; \mathrm{D}_{\mathrm{K} 2006}={ }_{\text {" }}+3$ ".

\section{Wnioski}

Przeprowadzone analizy wykazały, że spośród ponad 100 grup rozpoznań nowotworów istnieje około 35, które są istotne z punktu widzenia epidemiologii społecznej. Świadczy to, że Narodowy Program Zwalczania Nowotworów właśnie te choroby powinien traktować priorytetowo i dla nich powinna być opracowana szczegółowa strategia postępowania.

Istnieje około 20 grup rozpoznań, w których obliczony koszt innowacji przekroczył na przestrzeni trzech lat $50 \mathrm{mi}-$ lionów złotych (nowotwory, w leczeniu których wprowadzono nowe leki). Istnieje duża i utrzymująca się w badanym okresie rozbieżność (około 50\%) między wykazywanymi rozpoznaniami i rozpoznaniami potwierdzonymi lub chorymi leczonymi, co wymaga przeprowadzenia odrębnych i bardziej szczegółowych analiz.

\section{Dr n. o zdrowiu Andrzej Śliwczyński \\ Departament Gospodarki Lekami \\ Centrala NFZ \\ ul. Grójecka 186, 02-390 Warszawa \\ e-mail:Andrzej.Sliwczynski@nfz.gov.pl}

Otrzymano: 15 stycznia 2013 r.

Przyjęto do druku: 26 czerwca 2013 r. 


\section{Piśmiennictwo}

1. Ustawa z dnia 1 lipca 2005 r. o ustanowieniu programu wieloletniego "Narodowy program zwalczania chorób nowotworowych" (DZ. U. z 2005 r. Nr 143, poz. 1200).

2. http://www.kodekswalkizrakiem.pl/content/view/56/113/

3. Ustawa $z$ dnia 27.08.2004 r. o świadczeniach opieki zdrowotnej finansowanych ze środków publicznych (Dz. U. z 2008 r. Nr 164, poz. 1027, z późn. zm.).

4. Rozporządzenie Ministra Zdrowia z dnia 11.01.2010 r. zmieniające rozporządzenie w sprawie świadczeń gwarantowanych z zakresu programów zdrowotnych (Dz. U. z 2010 r. Nr 05, poz. 29, z późn. zm.).
5. Rozporządzenie Ministra Zdrowia z dnia 02.03.2010r. zmieniające rozporządzenie w sprawie świadczeń gwarantowanych z zakresu leczenia szpitalnego (Dz. U. z 2010 r. Nr 30, poz. 157, z późn. zm.)

6. Zarządzenie $\mathrm{nr}$ 101/2007/DGL 05.11.2007r. zmieniające zarządzenie w sprawie przyjęcia "Szczegółowych materiałów informacyjnych o przedmiocie postępowania w sprawie zawarcia umów o udzielanie świadczeń opieki zdrowotnej oraz o realizacji i finansowaniu umów o udzielanie świadczeń opieki zdrowotnej w rodzaju: leczenie szpitalne".

7. Zarządzenie nr 65/2009/DGL Prezesa NFZ z dnia 19.06.2008 r.w sprawie określenia warunków zawierania i realizacji umów w rodzaju leczenie szpitalne w zakresie terapeutyczne programy zdrowotne.

8. Porta M.Adictionary ofepidemiology. Oxford:Oxford University Press, 2008

W dniach 9-10 maja 2014 r. w Jastrzębiej Górze odbędą się

VII Pomorskie Spotkanie Uro-Onkologiczne

„Rak pęcherza moczowego - stagnacja czy postęp?"

Komitet Organizacyjny:

Przewodnicząca

dr med. Elżbieta Senkus-Konefka

dr med. Krzysztof Szkarłat

mgr Agnieszka Pliszka

mgr Joanna Sak

mgr Jadwiga Węsierska

Miejsce:

Hotel „ASTOR" w Jastrzębiej Górze

Informacje i rejestracja:

www.uro-onko.pl 
Tabela I. Populacja chorych z rozpoznaniami od C00 do D09 w latach 2002-2011 w podziale na rozpoznania

\begin{tabular}{|c|c|c|c|c|c|c|c|c|c|c|}
\hline populacj & & & & & & & & & & \\
\hline ICD-10 & 2002 & 2003 & 2004 & 2005 & 2006 & 2007 & 2008 & 2009 & 2010 & 2011 \\
\hline $\mathrm{COO}$ & 1643 & 2226 & 2933 & 3262 & 3449 & 3585 & 3892 & 4115 & 4325 & 4509 \\
\hline $\mathrm{C} 01$ & 552 & 601 & 728 & 821 & 895 & 944 & 992 & 1028 & 1083 & 1144 \\
\hline $\mathrm{C} 02$ & 639 & 704 & 847 & 963 & 1064 & 1122 & 1269 & 1423 & 1520 & 1593 \\
\hline $\mathrm{CO3}$ & 203 & 220 & 265 & 298 & 319 & 354 & 421 & 441 & 463 & 507 \\
\hline $\mathrm{CO4}$ & 965 & 1079 & 1291 & 1395 & 1494 & 1526 & 1612 & 1749 & 1887 & 1970 \\
\hline $\mathrm{C05}$ & 321 & 356 & 440 & 475 & 511 & 546 & 639 & 707 & 769 & 832 \\
\hline $\mathrm{C} 06$ & 376 & 415 & 508 & 542 & 589 & 656 & 724 & 796 & 847 & 895 \\
\hline $\mathrm{CO}$ & 746 & 838 & 1192 & 1348 & 1447 & 1546 & 1698 & 1805 & 1911 & 2014 \\
\hline $\mathrm{C} 08$ & 235 & 244 & 307 & 351 & 383 & 424 & 466 & 489 & 520 & 562 \\
\hline $\mathrm{CO9}$ & 1034 & 1162 & 1432 & 1592 & 1678 & 1776 & 1895 & 2011 & 2109 & 2262 \\
\hline C10 & 641 & 681 & 857 & 967 & 997 & 1049 & 1125 & 1178 & 1261 & 1309 \\
\hline C11 & 629 & 727 & 839 & 871 & 928 & 955 & 994 & 1045 & 1095 & 1177 \\
\hline C12 & 98 & 134 & 167 & 196 & 221 & 204 & 248 & 294 & 335 & 355 \\
\hline C13 & 642 & 669 & 770 & 853 & 897 & 897 & 944 & 1017 & 1029 & 1070 \\
\hline C14 & 262 & 246 & 771 & 839 & 927 & 884 & 782 & 827 & 806 & 918 \\
\hline C15 & 2109 & 2260 & 2680 & 2709 & 2788 & 2843 & 2874 & 2989 & 2973 & 3075 \\
\hline C16 & 9418 & 10254 & 12682 & 13627 & 14494 & 15067 & 15920 & 16373 & 17056 & 17822 \\
\hline C17 & 422 & 511 & 681 & 767 & 860 & 933 & 1045 & 1154 & 1279 & 1385 \\
\hline C18 & 18918 & 21580 & 28272 & 32746 & 36751 & 40608 & 45242 & 49281 & 53074 & 56605 \\
\hline C19 & 3024 & 3405 & 4233 & 4850 & 5211 & 5762 & 6383 & 6902 & 7473 & 8013 \\
\hline $\mathrm{C} 20$ & 15784 & 17741 & 22288 & 24822 & 26928 & 29013 & 31100 & 32852 & 34631 & 36400 \\
\hline $\mathrm{C} 21$ & 1234 & 1258 & 1507 & 1573 & 1699 & 1809 & 1815 & 1849 & 1879 & 1916 \\
\hline C22 & 1943 & 2235 & 2736 & 3026 & 3407 & 3520 & 3693 & 3819 & 3921 & 4144 \\
\hline $\mathrm{C} 23$ & 1459 & 1548 & 1796 & 1896 & 2035 & 2069 & 2239 & 2223 & 2356 & 2438 \\
\hline $\mathrm{C} 24$ & 507 & 590 & 769 & 836 & 941 & 1031 & 1088 & 1150 & 1204 & 1261 \\
\hline $\mathrm{C} 25$ & 4065 & 4584 & 5725 & 6426 & 6915 & 7077 & 7481 & 7778 & 7778 & 7904 \\
\hline $\mathrm{C} 26$ & 432 & 480 & 559 & 623 & 668 & 695 & 809 & 922 & 910 & 862 \\
\hline C30 & 313 & 367 & 461 & 511 & 549 & 567 & 640 & 682 & 735 & 747 \\
\hline C31 & 400 & 435 & 570 & 650 & 682 & 725 & 822 & 893 & 940 & 953 \\
\hline C32 & 11372 & 12537 & 15567 & 16852 & 17568 & 18115 & 19075 & 19657 & 20071 & 20565 \\
\hline C33 & 82 & 93 & 113 & 115 & 112 & 110 & 122 & 115 & 125 & 121 \\
\hline C34 & 37310 & 39196 & 46507 & 50248 & 52761 & 54448 & 56285 & 57277 & 57834 & 58657 \\
\hline C37 & 143 & 160 & 234 & 276 & 302 & 324 & 377 & 393 & 421 & 443 \\
\hline C38 & 391 & 398 & 551 & 570 & 637 & 627 & 666 & 727 & 772 & 787 \\
\hline C39 & 121 & 122 & 142 & 152 & 187 & 176 & 224 & 225 & 253 & 253 \\
\hline $\mathrm{C} 40$ & 1037 & 1178 & 1475 & 1687 & 1839 & 1951 & 2127 & 2300 & 2475 & 2657 \\
\hline C41 & 574 & 653 & 1191 & 1383 & 1522 & 1579 & 1956 & 2036 & 2022 & 2127 \\
\hline C43 & 7549 & 8796 & 11292 & 12848 & 14172 & 15336 & 16865 & 18508 & 19967 & 21776 \\
\hline C44 & 21663 & 23931 & 36672 & 46912 & 56605 & 65562 & 78346 & 89315 & 100355 & 111825 \\
\hline $\mathrm{C} 45$ & 161 & 181 & 228 & 285 & 316 & 357 & 393 & 427 & 465 & 489 \\
\hline $\mathrm{C} 46$ & 99 & 95 & 135 & 146 & 148 & 156 & 176 & 194 & 195 & 209 \\
\hline C47 & 225 & 258 & 341 & 374 & 409 & 451 & 487 & 516 & 576 & 619 \\
\hline $\mathrm{C} 48$ & 446 & 554 & 714 & 763 & 845 & 921 & 1033 & 1165 & 1288 & 1385 \\
\hline C49 & 2193 & 2600 & 3491 & 3962 & 4355 & 4679 & 5206 & 5666 & 6161 & 6725 \\
\hline
\end{tabular}


Tabela I. cd. Populacja chorych z rozpoznaniami od C00 do D09 w latach 2002-2011 w podziale na rozpoznania

\begin{tabular}{|c|c|c|c|c|c|c|c|c|c|c|}
\hline populacj & & & & & & & & & & \\
\hline ICD-10 & 2002 & 2003 & 2004 & 2005 & 2006 & 2007 & 2008 & 2009 & 2010 & 2011 \\
\hline C50 & 73066 & 81925 & 103549 & 114205 & 123252 & 132466 & 143661 & 153441 & 163469 & 174144 \\
\hline C51 & 1336 & 1451 & 1867 & 2186 & 2497 & 2771 & 2924 & 3060 & 3304 & 3467 \\
\hline C52 & 299 & 349 & 429 & 459 & 467 & 486 & 505 & 510 & 525 & 559 \\
\hline C53 & 16582 & 18089 & 22605 & 24583 & 26005 & 27288 & 29116 & 30581 & 31952 & 33530 \\
\hline C54 & 16219 & 18273 & 23604 & 26565 & 29137 & 31590 & 35307 & 38455 & 41816 & 45462 \\
\hline C55 & 312 & 347 & 422 & 453 & 501 & 545 & 580 & 607 & 595 & 627 \\
\hline C56 & 12025 & 13538 & 16644 & 18108 & 19351 & 20259 & 21747 & 22965 & 24298 & 25795 \\
\hline C57 & 241 & 268 & 329 & 349 & 363 & 394 & 437 & 484 & 511 & 551 \\
\hline C58 & 107 & 88 & 148 & 174 & 204 & 227 & 245 & 289 & 323 & 368 \\
\hline $\mathrm{C60}$ & 564 & 622 & 823 & 939 & 1050 & 1098 & 1226 & 1322 & 1387 & 1472 \\
\hline C61 & 27231 & 31230 & 43822 & 50567 & 56211 & 61559 & 67244 & 72749 & 77626 & 82751 \\
\hline C62 & 4047 & 4782 & 6065 & 6721 & 7351 & 7822 & 8690 & 9559 & 10372 & 11478 \\
\hline C63 & 64 & 68 & 98 & 94 & 102 & 121 & 150 & 140 & 170 & 179 \\
\hline C64 & 12860 & 14559 & 20130 & 23828 & 26724 & 29451 & 33438 & 36786 & 40347 & 43741 \\
\hline C65 & 188 & 222 & 293 & 341 & 373 & 440 & 569 & 619 & 682 & 757 \\
\hline $\mathrm{C66}$ & 103 & 127 & 169 & 198 & 219 & 248 & 284 & 315 & 360 & 396 \\
\hline C67 & 19537 & 21861 & 29072 & 33155 & 36333 & 39293 & 43738 & 47480 & 50914 & 54133 \\
\hline C68 & 128 & 150 & 422 & 640 & 628 & 634 & 631 & 611 & 642 & 676 \\
\hline C69 & 1478 & 2112 & 2759 & 3185 & 3640 & 3960 & 4481 & 4803 & 5263 & 5745 \\
\hline $\mathrm{C} 70$ & 293 & 354 & 517 & 630 & 745 & 820 & 935 & 1039 & 1136 & 1224 \\
\hline C71 & 7800 & 9047 & 12338 & 14256 & 15652 & 16591 & 18131 & 19299 & 20250 & 21530 \\
\hline C72 & 673 & 782 & 1045 & 1249 & 1396 & 1521 & 1633 & 1768 & 1890 & 2001 \\
\hline C73 & 8492 & 11137 & 13532 & 15194 & 16892 & 18376 & 20364 & 22113 & 24099 & 26190 \\
\hline C74 & 356 & 426 & 554 & 655 & 732 & 792 & 894 & 966 & 1061 & 1163 \\
\hline $\mathrm{C} 75$ & 202 & 205 & 337 & 411 & 511 & 601 & 700 & 815 & 889 & 1015 \\
\hline C76 & 779 & 803 & 1007 & 1217 & 1581 & 2142 & 3086 & 3611 & 3899 & 4186 \\
\hline C77 & 345 & 357 & 393 & 429 & 478 & 511 & 526 & 574 & 614 & 673 \\
\hline $\mathrm{C} 78$ & 368 & 403 & 456 & 446 & 490 & 478 & 602 & 803 & 953 & 1100 \\
\hline $\begin{array}{l}\mathrm{C} 79 \\
\end{array}$ & 472 & 472 & 697 & 790 & 804 & 844 & 926 & 1054 & 1195 & 1405 \\
\hline $\mathrm{C} 80$ & 2617 & 3111 & 4560 & 5202 & 5528 & 5827 & 5763 & 5459 & 5655 & 6014 \\
\hline C81 & 5326 & 6054 & 7710 & 8258 & 8726 & 8970 & 9536 & 10024 & 10546 & 11174 \\
\hline C82 & 2799 & 3103 & 3819 & 4142 & 4365 & 4416 & 4491 & 4466 & 4534 & 4633 \\
\hline C83 & 3548 & 4071 & 5209 & 5882 & 6483 & 7162 & 7801 & 8312 & 8910 & 9313 \\
\hline C84 & 415 & 481 & 652 & 731 & 826 & 955 & 1117 & 1254 & 1341 & 1472 \\
\hline $\mathrm{C} 85$ & 1492 & 1587 & 1908 & 2053 & 2114 & 2209 & 2425 & 2694 & 3055 & 3446 \\
\hline C88 & 442 & 448 & 573 & 640 & 696 & 698 & 748 & 793 & 819 & 820 \\
\hline $\mathrm{C} 90$ & 3928 & 4256 & 5225 & 5753 & 6198 & 6506 & 7108 & 7520 & 7998 & 8528 \\
\hline C91 & 10368 & 11373 & 14195 & 15399 & 16263 & 17003 & 18194 & 19266 & 20294 & 21288 \\
\hline C92 & 3040 & 3443 & 4348 & 4857 & 5174 & 5338 & 5676 & 5950 & 6229 & 6521 \\
\hline C93 & 45 & 59 & 82 & 110 & 112 & 117 & 150 & 193 & 213 & 192 \\
\hline C94 & 360 & 432 & 532 & 587 & 633 & 641 & 756 & 872 & 935 & 1008 \\
\hline C95 & 53 & 47 & 79 & 87 & 95 & 111 & 121 & 129 & 117 & 129 \\
\hline C96 & 784 & 862 & 1129 & 1281 & 1361 & 1424 & 1541 & 1598 & 1644 & 1708 \\
\hline C97 & 353 & 356 & 434 & 445 & 477 & 504 & 486 & 451 & 441 & 452 \\
\hline $\mathrm{D} 00$ & 4 & 5 & 129 & 194 & 216 & 253 & 313 & 352 & 368 & 416 \\
\hline D01 & 5 & 5 & 113 & 134 & 150 & 162 & 202 & 228 & 268 & 312 \\
\hline D02 & 2 & 2 & 18 & 23 & 35 & 49 & 66 & 80 & 94 & 117 \\
\hline D03 & 2 & 6 & 37 & 59 & 82 & 103 & 128 & 160 & 216 & 278 \\
\hline D04 & 52 & 70 & 1001 & 1671 & 2289 & 2824 & 3540 & 4150 & 5052 & 6069 \\
\hline D05 & 48 & 63 & 291 & 421 & 530 & 647 & 755 & 892 & 1069 & 1328 \\
\hline D06 & 38 & 46 & 444 & 592 & 702 & 812 & 924 & 1012 & 1126 & 1297 \\
\hline D07 & 5 & 8 & 69 & 97 & 131 & 155 & 175 & 230 & 268 & 287 \\
\hline
\end{tabular}


Tabela IV. Sumaryczne koszty leczenia chorych z rozpoznaniami C00 do D09 w latach 2002-2011 (wartość w złotych)

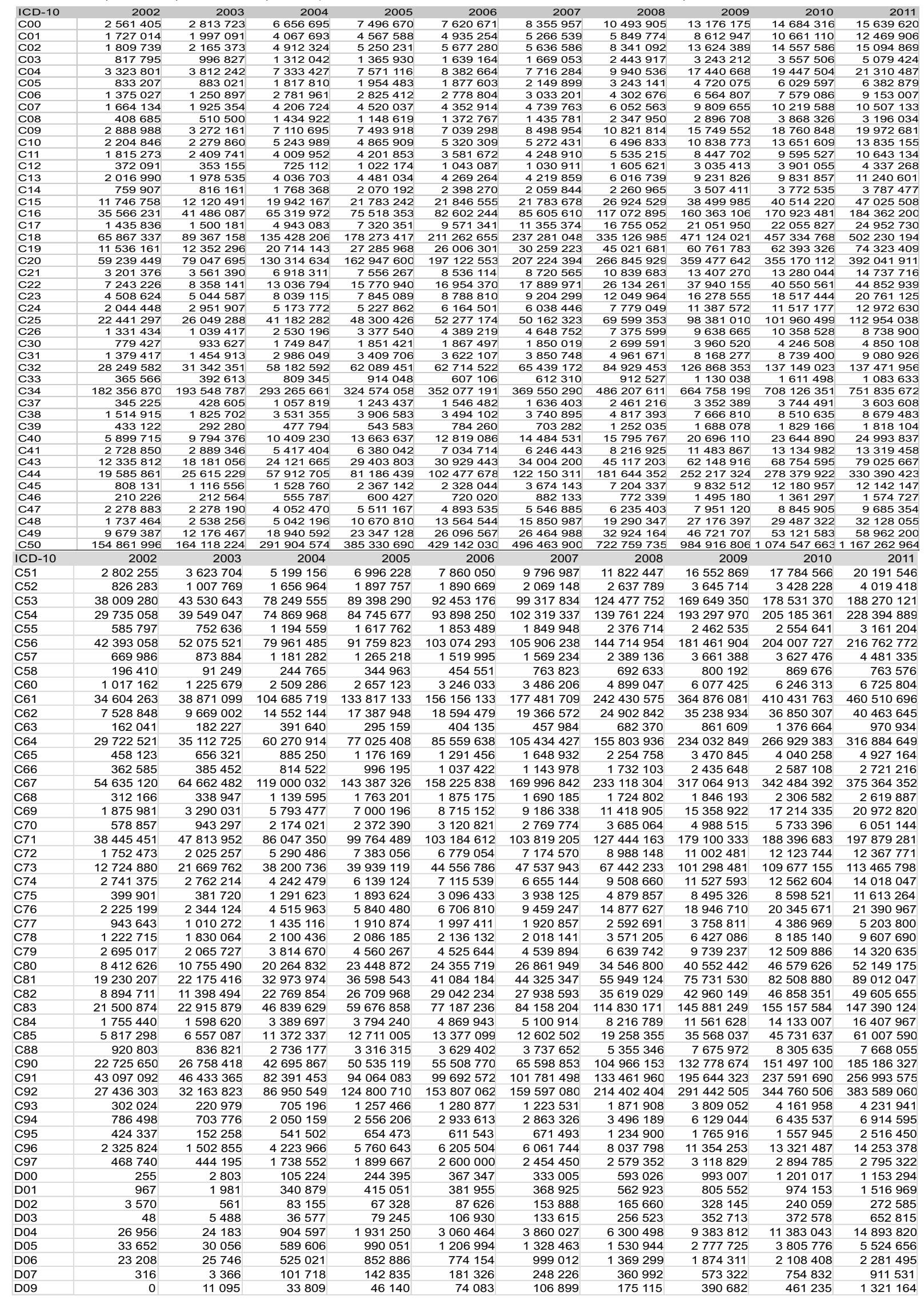


Tabela VIII. Koszty innowacji w latach 2004, 2008 i 2009

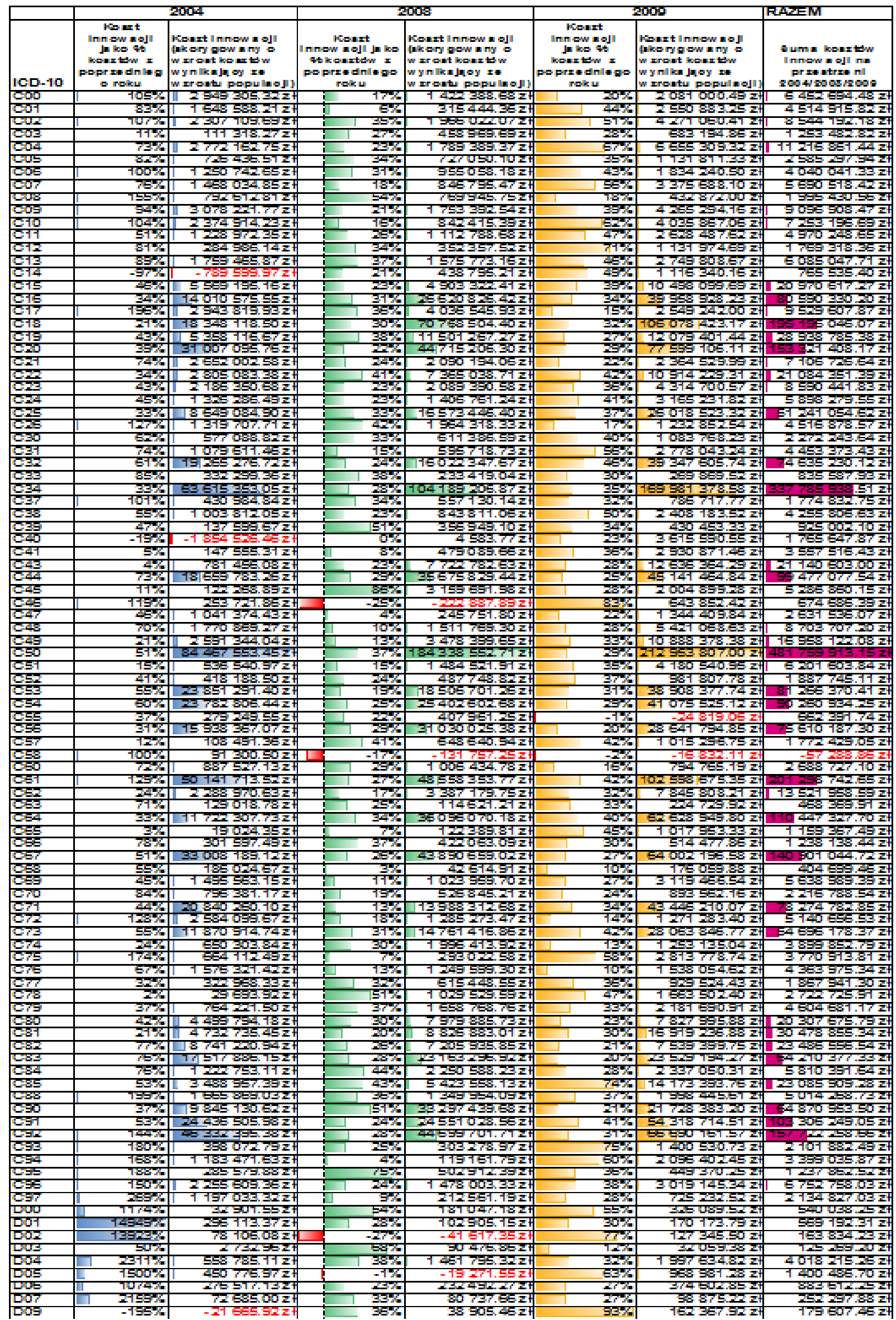

